Article

\title{
Ultrasonic Shaking of Glauconite Pellets with Diverse Reagents for a Comparison of Their K-Ar with Already Published Rb-Sr Results
}

\author{
Norbert Clauer ${ }^{1, *}$, Edward Keppens ${ }^{2}$, I. Tonguç Uysal ${ }^{3}$ and Amélie Aubert ${ }^{1}$ \\ 1 Institut des Sciences de la Terre et de l'Environnement, Université de Strasbourg (UdS/CNRS), \\ 67084 Strasbourg, France; aaubert@unistra.fr \\ 2 Department of Chemistry, Vrije Universiteit Brussel, BE-1050 Brussels, Belgium; ekeppens@vub.be \\ 3 Department of Geology, Faculty of Engineering, University of Istanbul-Cerrahpasa, Istanbul 34500, Turkey; \\ t.uysal@uq.edu.au \\ * Correspondence: nclauer@unistra.fr
}

check for updates

Citation: Clauer, N.; Keppens, E.; Uysal, I.T.; Aubert, A. Ultrasonic Shaking of Glauconite Pellets with Diverse Reagents for a Comparison of Their K-Ar with Already Published Rb-Sr Results. Geosciences 2021, 11, 439. https://doi.org/10.3390/ geosciences11110439

Academic Editors: Suzanne Golding and Jesus Martinez-Frias

Received: 28 August 2021

Accepted: 18 October 2021

Published: 25 October 2021

Publisher's Note: MDPI stays neutral with regard to jurisdictional claims in published maps and institutional affiliations.

Copyright: (c) 2021 by the authors. Licensee MDPI, Basel, Switzerland. This article is an open access article distributed under the terms and conditions of the Creative Commons Attribution (CC BY) license (https:/ / creativecommons.org/licenses/by/ $4.0 /)$.
Abstract: A combined ultrasonic treatment, with de-ionized $\mathrm{H}_{2} \mathrm{O}$, dilute $\mathrm{HAc}$ or dilute $\mathrm{HCl}$, of three Mid-Miocene glauconite samples was applied to $\mathrm{K}-\mathrm{Ar}$ date the different separates in order to compare the results with those obtained by the $\mathrm{Rb}-\mathrm{Sr}$ method using the same three samples and that were analyzed strictly in the same way. Two aliquots yield opposite elemental and K-Ar trends, which suggests different initial mineral compositions for the various pellets. The K-Ar data of two untreated and leached L7 and L8 aliquots are almost within analytical uncertainty from $17.3 \pm 0.6 \mathrm{Ma}$ to $19.6 \pm 0.7 \mathrm{Ma}(2 \sigma)$, while those of the third L10 sample are slightly higher at $22.1 \pm 1.2 \mathrm{Ma}(2 \sigma)$. Comparatively, the earlier published $\mathrm{Rb}-\mathrm{Sr}$ ages of the three untreated samples and of the leached aliquots gave similar data for the L7 aliquots by an isochron at $18.1 \pm 3.1(2 \sigma)$ Ma and for the sample L8 by an isochron with an age of $19.6 \pm 1.8(2 \sigma) \mathrm{Ma}$, while the untreated L10 aliquot yields a very high $\mathrm{Rb}-\mathrm{Sr}$ date of $42.1 \pm 1.6(2 \sigma) \mathrm{Ma}$. This untreated L10 glauconite fraction contains blödite, a Sr-rich carbonate that impacted the two isotopic systems differently. Generally, dilute $\mathrm{HCl}$ or HAc acids dissolve carbonates, sulfates, sulfites and oxides, while they do not affect the clay-type crystals such as glauconites. These soluble minerals can be identified indirectly, as here, by X-ray diffraction and the amounts of leached $\mathrm{Na}_{2} \mathrm{O}, \mathrm{CaO}$ and $\mathrm{Fe}_{2} \mathrm{O}_{3}$ contents. Together with the leaching of some metallic trace elements, those of $\mathrm{NaO}$ confirm the leaching of metals and of blödite that are both hosted by the glauconite pellets. The occurrence of this Sr-enriched mineral explains the age differences of the non-treated aliquots and suggests a systematic leaching of any glauconite separate before isotope determination and, possibly, a comparison of the $\mathrm{Rb}-\mathrm{Sr}$ and $\mathrm{K}-\mathrm{Ar}$ results. Ultrasonic shaking appears appropriate for physical disaggregation of any contaminating grains that may remain hosted within the pellets, even after a preliminary $\mathrm{H}_{2} \mathrm{O}$ wash, which may dissolve and remove the soluble minerals but not the $\mathrm{H}_{2} \mathrm{O}$-insoluble silicates. The $\mathrm{K}-\mathrm{Ar}$ study completed here as a complement to a previous $\mathrm{Rb}-\mathrm{Sr}$ study highlights, again, the importance of the preparation step in isotopic studies of glauconite-type and, by extension, of any clay material, as all occurring minerals can interfere in the final age determinations and, therefore, differently in the mineral assemblages. All those not in isotopic equilibrium need to be removed before analysis, including the soluble Sr or alkali-enriched ones.

Keywords: glauconite pellets; dilute acid leaching experiments; various ultrasonic treatments; various leaching reagents; major and trace chemical compositions; blödite; K-Ar ages; previously published $\mathrm{Rb}-\mathrm{Sr}$ data

\section{Introduction}

Because of their wide geographic and stratigraphic occurrence, authigenic glauconite minerals of various types of sediments have long been considered as reference materials for 
the calibration of time scale and were, therefore, studied in detail in many basic mineralogical and chemical studies and reviews e.g., [1-3]. In addition, since Cormier's [4] pioneer $\mathrm{Rb}-\mathrm{Sr}$ age dating of glauconites, many $\mathrm{Rb}-\mathrm{Sr}$ and $\mathrm{K}-\mathrm{Ar}$ dating studies were based on this mineral e.g., [5-9]. The ${ }^{40} \mathrm{Ar} /{ }^{39} \mathrm{Ar}$ method was also applied [10], even being considered as successful [11]. Expectedly, some of the published isotopic ages of glauconite separates were also questioned [12], especially because of the preparation methods due to the specific "granular" aspect of the target mineral. The systematic occurrence of agglomerated pellets often raised a concern about cleaning the intergrowths with the removal of potentially trapped detrital grains, which may explain why various preparation techniques were attempted. For instance, Odin and Hunziker [13] presented a preparation sequence of green aggregates based on leaching with dilute acetic acid combined with an ultrasonic treatment to remove any foreign particle, authigenic or detrital, from glauconite grains. Earlier, Pasteels et al. [6] and Keppens [14] chose dilute hydrochloric acid as the reagent, also with an ultrasonic shaking, whereas other authors preferred ammonium-acetate leaching without shaking e.g., [7,15]. In this context, Clauer et al. [16] examined isotopic data based on various preparation methods used by different investigators to focus on the most appropriate preparation. This survey demonstrated that the main reasons for analytical discrepancies were due to various separation and purification procedures of the clay types. Analytical aspects are precisely addressed here again by focusing more specifically on the ultrasonic shaking of glauconite separates strictly using the same procedure as Pasteels et al. [6] with the same reagents during the same shaking durations, and by comparing the $\mathrm{K}-\mathrm{Ar}$ data obtained here with their $\mathrm{Rb}-\mathrm{Sr}$ data published long ago.

While different types of reagents were extensively tested on illite particles, physical ultrasonic treatments combined with either dilute $\mathrm{HCl}$ or $\mathrm{HAc}$ were not used as often to clean glauconite pellets. In fact, detrital particles may adhere to or may even be included into growing glauconite pellets, which can bias the stratigraphic message that these green grains are expected to convey. In the present analytical context, the aim was also to complement a pioneering study on the topic by Pasteels et al. [6], by analyzing the chemical composition of strictly the same glauconite separates than these authors, and by applying $\mathrm{K}-\mathrm{Ar}$ analyses on them before and after the same ultrasonic treatments.

\section{Description of the Selected Samples and of the Analytical Procedure}

Three samples located next to each other in a lenticular glauconite-rich horizon of Antwerp sands were collected from an access favored by a local road work along highway E3 near the city of Antwerp in Belgium [6]. The glauconite aggregates of these coarse sands were so enriched that pure separates were obtained by dry sieving followed by a magnetic separation. Independently to their stratigraphic dating by isotopic methods, the host Antwerp sands were considered to be Middle Miocene, based on descriptions of their calcareous nanoplancton (about 18 Ma referring to Berggren's scale, [17]. The three untreated glauconite fractions were analyzed hereunder for their contents of major and trace elements, as well as for their $\mathrm{K}-\mathrm{Ar}$ isotopic ages. Each sample was then split into several aliquots that were leached with different reagents and subjected to various 'ultrasonic treatments, as were those analyzed by Pasteels et al. [6]. De-ionized water, as well as ultra-pure $1.7 \mathrm{~N}$ acetic acid and $1 \mathrm{~N}$ hydrochloric acid, were used for the preanalytical procedure (Table 1). 
Table 1. (A) Contents of major elements in the untreated and leached glauconite pellets; (B) Positive and negative variations in the content of major elements of the leached separates, relative to the untreated reference sample. The numbers in brackets identify the successive aliquots; bdl stands for below detection limit.

\begin{tabular}{|c|c|c|c|c|c|c|c|c|c|c|c|}
\hline \multicolumn{12}{|c|}{ (A) } \\
\hline Sample IDs & $\begin{array}{c}\mathrm{SiO}_{2} \\
(\%)\end{array}$ & $\begin{array}{c}\mathrm{Al}_{2} \mathrm{O}_{3} \\
(\%)\end{array}$ & $\begin{array}{c}\mathrm{MgO} \\
(\%)\end{array}$ & $\begin{array}{c}\mathrm{CaO} \\
(\%)\end{array}$ & $\begin{array}{c}\mathrm{Fe}_{2} \mathrm{O}_{3} \\
(\%)\end{array}$ & $\begin{array}{c}\mathrm{Mn}_{3} \mathrm{O}_{4} \\
(\%)\end{array}$ & $\begin{array}{c}\mathrm{TiO}_{2} \\
(\%)\end{array}$ & $\begin{array}{c}\mathrm{Na}_{2} \mathrm{O} \\
(\%)\end{array}$ & $\begin{array}{c}\mathrm{K}_{2} \mathrm{O} \\
(\%)\end{array}$ & $\begin{array}{l}\text { LOI } \\
(\%)\end{array}$ & $\begin{array}{c}\text { Total } \\
(\%)\end{array}$ \\
\hline L7 untreated $(=1)$ & 48.6 & 6.30 & 3.60 & 0.40 & 25.3 & 0.010 & 0.07 & 0.12 & 7.24 & 6.76 & 98.40 \\
\hline $\mathrm{US} \mathrm{H}_{2} \mathrm{O} 20^{\prime}(=2)$ & 47.8 & 6.40 & 3.57 & 0.50 & 24.2 & 0.010 & 0.06 & 0.12 & 7.34 & 8.27 & 98.27 \\
\hline US HAc $20^{\prime}(=3)$ & 48.9 & 6.10 & 3.53 & 0.30 & 24.1 & 0.013 & 0.07 & 0.11 & 7.33 & 8.47 & 98.92 \\
\hline US HCl $20^{\prime}(=4)$ & 49.3 & 6.20 & 3.52 & bdl & 24.4 & 0.014 & 0.08 & 0.14 & 7.52 & 7.75 & 98.92 \\
\hline US HCl $60^{\prime}(=5)$ & 50.4 & 6.20 & 3.55 & bdl & 24.5 & 0.01 & 0.06 & 0.13 & 7.13 & 8.33 & 100.3 \\
\hline US $\mathrm{H}_{2} \mathrm{O}+$ US HAc $(=6)$ & 49.3 & 6.00 & 3.69 & 0.30 & 25.4 & 0.015 & 0.06 & 0.10 & 7.42 & 8.92 & 101.2 \\
\hline L8 untreated $(=1)$ & 48.9 & 6.60 & 3.60 & 0.40 & 24.6 & 0.016 & 0.07 & 0.09 & 7.37 & 6.99 & 98.64 \\
\hline $\mathrm{US} \mathrm{H}_{2} \mathrm{O} 20^{\prime}(=2)$ & 50.0 & 6.20 & 3.63 & 0.40 & 24.9 & 0.012 & 0.07 & 0.09 & 7.29 & 7.89 & 100.5 \\
\hline US HAc $20^{\prime}(=3)$ & 49.6 & 6.40 & 3.66 & 0.30 & 25.0 & 0.013 & 0.07 & 0.05 & 7.31 & 8.80 & 101.2 \\
\hline US HCl $20^{\prime}(=4)$ & 47.6 & 5.90 & 3.60 & bdl & 24.6 & 0.016 & 0.06 & 0.07 & 7.20 & 9.73 & 98.78 \\
\hline $\mathrm{US} \mathrm{H}_{2} \mathrm{O} 60^{\prime}(=5)$ & 49.4 & 6.40 & 3.60 & bdl & 24.7 & 0.010 & 0.06 & 0.07 & 7.32 & 8.23 & 99.79 \\
\hline US $\mathrm{H}_{2} \mathrm{O} 24 \mathrm{~h}(=6)$ & 49.5 & 6.30 & 3.56 & bdl & 24.5 & 0.010 & 0.07 & 0.09 & 7.38 & 8.20 & 99.61 \\
\hline L10 untreated $(=1)$ & 48.9 & 7.70 & 3.57 & 0.50 & 24.0 & 0.015 & 0.14 & 0.08 & 7.14 & 6.96 & 99.01 \\
\hline US HAc $20^{\prime}(=3)$ & 49.9 & 7.10 & 3.56 & 0.30 & 23.5 & 0.011 & 0.08 & 0.30 & 7.12 & 8.74 & 100.6 \\
\hline $\mathrm{US} \mathrm{HCl} 20^{\prime}(=4)$ & 49.8 & 7.30 & 3.54 & bdl & 23.2 & 0.014 & 0.12 & 0.16 & 7.12 & 8.71 & 99.96 \\
\hline US $\mathrm{H}_{2} \mathrm{O}+$ US HAc $(=5)$ & 49.2 & 7.60 & 3.67 & 0.30 & 24.2 & 0.012 & 0.10 & 0.07 & 7.28 & 7.78 & 100.2 \\
\hline $\mathrm{USH}_{2} \mathrm{O}+\mathrm{USHAc}(2 \times)(=6)$ & 48.2 & 7.00 & 3.53 & 0.20 & 24.8 & 0.016 & 0.09 & 0.11 & 7.21 & 7.07 & 98.23 \\
\hline \multicolumn{12}{|c|}{ (B) } \\
\hline Sample IDs & $\begin{array}{c}\mathrm{SiO}_{2} \\
(\%)\end{array}$ & $\begin{array}{c}\mathrm{Al}_{2} \mathrm{O}_{3} \\
(\%)\end{array}$ & $\begin{array}{c}\mathrm{MgO} \\
(\%)\end{array}$ & $\begin{array}{c}\mathrm{CaO} \\
(\%)\end{array}$ & $\begin{array}{c}\mathrm{Fe}_{2} \mathrm{O}_{3} \\
(\%)\end{array}$ & $\begin{array}{c}\mathrm{Mn}_{3} \mathrm{O}_{4} \\
(\%)\end{array}$ & $\begin{array}{c}\mathrm{TiO}_{2} \\
(\%)\end{array}$ & $\begin{array}{c}\mathrm{Na}_{2} \mathrm{O} \\
(\%)\end{array}$ & $\begin{array}{c}\mathrm{K}_{2} \mathrm{O} \\
(\%)\end{array}$ & $\begin{array}{l}\text { LOI } \\
(\%)\end{array}$ & $\begin{array}{c}\text { Total } \\
(\%)\end{array}$ \\
\hline L7 untreated $(=1)$ & 0 & 0 & 0 & 0 & 0 & 0 & 0 & 0 & 0 & 0 & 0 \\
\hline $\mathrm{US} \mathrm{H}_{2} \mathrm{O} 20^{\prime}(=2)$ & -1.6 & +1.6 & +0.8 & -25 & -4.3 & 0 & -14.3 & 0 & +1.4 & -22.3 & +0.1 \\
\hline US HAc $20^{\prime}(=3)$ & +0.6 & -3.2 & +1.9 & -25 & -4.7 & -30.0 & 0 & -8.3 & +1.2 & -25.3 & +0.1 \\
\hline $\mathrm{US} \mathrm{HCl} 20^{\prime}(=4)$ & +1.4 & +1.6 & +2.2 & & -3.6 & -40.0 & -14.3 & -16.7 & -3.9 & -11.6 & +0.5 \\
\hline US HCl $60^{\prime}(=5)$ & +3.7 & +1.6 & +1.4 & & -3.2 & -90.0 & -14.3 & +8.3 & +1.5 & -23.2 & +1.9 \\
\hline US $\mathrm{H}_{2} \mathrm{O}+$ US HAc $(=6)$ & +1.4 & -4.8 & +2.5 & -25 & +0.4 & -50.0 & -14.3 & -16.7 & +2.5 & -32.8 & +2.8 \\
\hline L8 untreated $(=1)$ & 0 & 0 & 0 & 0 & 0 & 0 & 0 & 0 & 0 & 0 & 0 \\
\hline $\mathrm{US} \mathrm{H}_{2} \mathrm{O} 20^{\prime}(=2)$ & +2.2 & -6.1 & +0.8 & 0 & +1.2 & -25.0 & 0 & 0 & +1.1 & -12.9 & +2.0 \\
\hline US HAc $20^{\prime}(=3)$ & +1.4 & -3.1 & +1.7 & -25 & +1.6 & -18.8 & 0 & -44.4 & +0.8 & -25.9 & -2.8 \\
\hline $\mathrm{US} \mathrm{HCl} 20^{\prime}(=4)$ & -2.7 & -10.6 & 0 & & 0 & 0 & -14.3 & -22.2 & +2.3 & -39.2 & +0.1 \\
\hline $\mathrm{US} \mathrm{H}_{2} \mathrm{O} 1 \mathrm{~h}(=5)$ & +1.0 & -3.1 & 0 & & +0.4 & -37.5 & -14.3 & -22.2 & +0.7 & -17.7 & +1.2 \\
\hline US $\mathrm{H}_{2} \mathrm{O} 24 \mathrm{~h}(=6)$ & $>1.2$ & -4.5 & +1.1 & & +0.4 & -37.5 & 0 & 0 & +0.1 & & +1.0 \\
\hline L10 untreated $(=1)$ & 0 & 0 & 0 & 0 & 0 & 0 & 0 & 0 & 0 & 0 & 0 \\
\hline US HAc $20^{\prime}(=3)$ & +2.0 & -7.8 & +0.3 & -40 & +2.1 & -26.7 & -42.9 & -2750 & +0.3 & -25.6 & +1.6 \\
\hline US HCl $20^{\prime}(=4)$ & +1.9 & -5.2 & +0.8 & & +3.3 & -6.7 & -14.3 & -2000 & +0.3 & -25.1 & +1.0 \\
\hline $\mathrm{US}_{2} \mathrm{O}+\mathrm{US} \mathrm{HAc}(=5)$ & +0.6 & +1.3 & -2.8 & -40 & +0.8 & -20.0 & -28.6 & -125 & +2.2 & -11.8 & +1.0 \\
\hline $\left.\mathrm{USH}_{2} \mathrm{O}+\mathrm{USHAc}(2 \times)(=6)\right)$ & -1.4 & -9.1 & +1.1 & -60 & -3.3 & -6.7 & -35.7 & -375 & +1.0 & +1.6 & +0.8 \\
\hline
\end{tabular}

The major elements were analyzed on an inductively coupled plasma atomic emission spectrometer (ICP-AES) and the trace elements on an inductively coupled plasma mass spectrometer (ICP-MS), by following the procedure of Samuel et al. [18]. The analytical accuracy of the analyses was monitored by measuring known standard materials in between successive samples, which resulted in an internal reproducibility of $\pm 2.5 \%$ for the major elements and of $\pm 5 \%$ for the trace elements. The Ar extractions were made in a glass extraction line directly connected to a static gas mass spectrometer after preheating the samples under vacuum at $80^{\circ} \mathrm{C}$ for at least $12 \mathrm{~h}$. The use of this step was to reduce the amount of atmospheric Ar that could have adhered to the glauconite grains during preparation, handling and analysis. The accuracy of the K-Ar method was checked weekly by measuring the international glauconite standard GL-O that averaged $24.59 \pm 0.17(2 \sigma) \times 10^{-6} \mathrm{~cm}^{3} / \mathrm{g}(\mathrm{STP})$ radiogenic ${ }^{40} \mathrm{Ar}$ for five independent measurements at the time of the study, to be compared to the recommended standard value of $24.85 \pm 0.48(2 \sigma) \times 10^{-6} \mathrm{~cm}^{3} / \mathrm{g}$ [19]. The procedure also included periodic determinations of atmospheric loads, which ${ }^{40} \mathrm{Ar} /{ }^{36} \mathrm{Ar}$ ratio averaged $298.7 \pm 1.2(2 \sigma)$, to be compared to the recommended value of $298.6 \pm 0.4(2 \sigma)$ [20] The blanks of the coupled extraction line and mass spectrometer were also verified once a 
week for their content of radiogenic ${ }^{40} \mathrm{Ar}$ that never exceeded $1 \times 10^{-8}$, more often being below $1 \times 10^{-9}$, which means that the equipment did not add measurable amounts of residual ${ }^{40} \mathrm{Ar}$ to that of the samples. The K-Ar ages were calculated using the decay constants recommended by Steiger and Jäger [21] with their individual analytical uncertainties. Further details of the analytical procedure are available in Bonhomme et al. [22].

\section{Results}

\subsection{The Variations of the Major Elements}

The contents of the major elements of the three untreated glauconite samples were compared to the aliquots submitted to ultrasonic shaking in different reagents (Figure 1; Table 1A). The variations in the $\mathrm{SiO}_{2}$ content scattered slightly below the analytical uncertainty of $\pm 2.5 \%$, except for the HCl-leached aliquots of the samples L7 and L8 (Table 1B). The $\mathrm{Al}_{2} \mathrm{O}_{3}$ content varied more, especially in the samples $\mathrm{L} 8$ and L10 with variations beyond analytical uncertainty. The variations in the $\mathrm{MgO}$ content were smaller, with only one decrease beyond the uncertainty limit. By contrast, the content of $\mathrm{CaO}$ decreased significantly in the acid-treated aliquots, suggesting an efficient dissolution of a soluble Ca-rich mineral. The $\mathrm{Fe}_{2} \mathrm{O}_{3}$ content also decreased significantly in most acid-treated separates of the samples L7 and L10, while it scattered within uncertainty in sample L8. The $\mathrm{Mn}_{3} \mathrm{O}_{4}$ content increased in the leachates, while those of $\mathrm{TiO}_{2}$ and $\mathrm{Na}_{2} \mathrm{O}$ decreased, those of $\mathrm{K}_{2} \mathrm{O}$ remaining within uncertainty. The loss on ignition systematically increased, while the total contents of the major elements increased, again slightly, for all aliquots of the three samples.
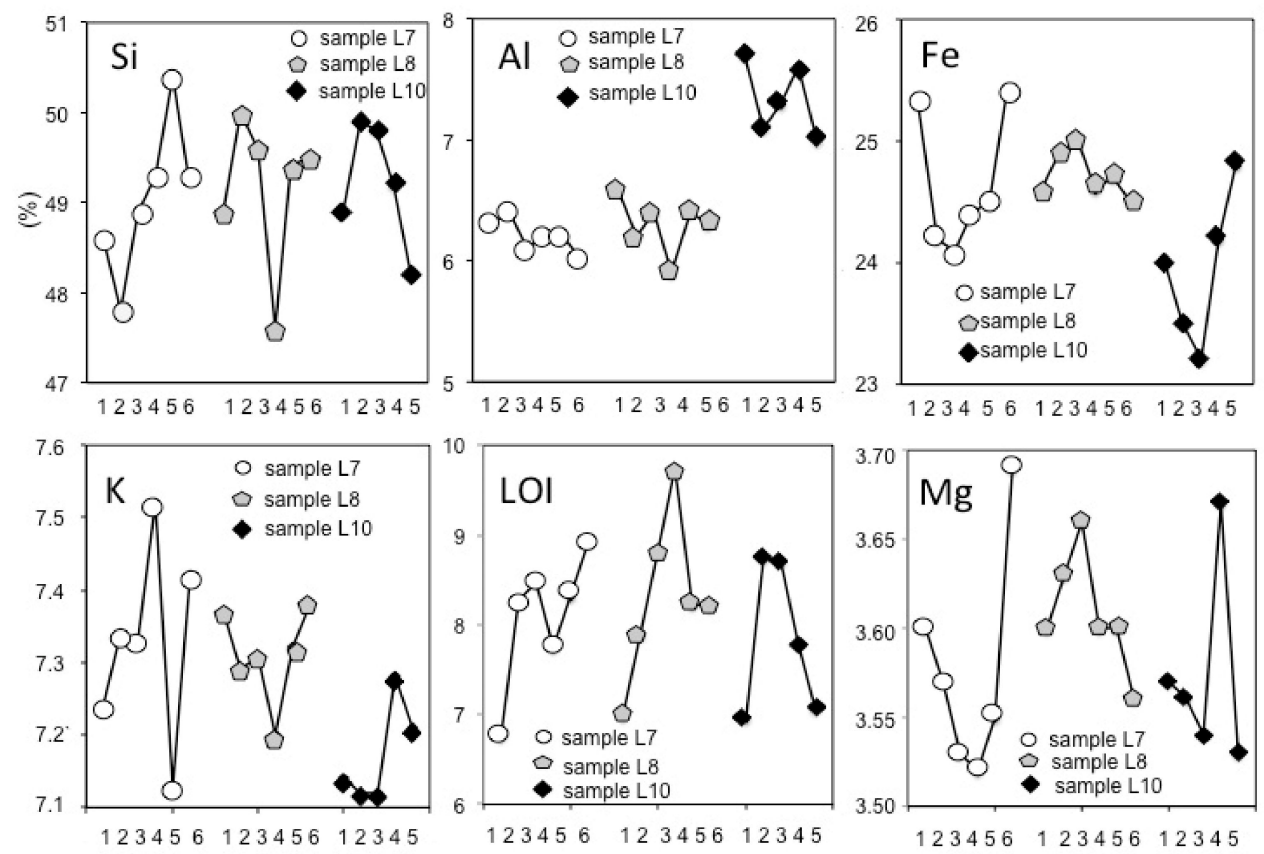

Figure 1. The analytical variations of the major elements leached from the three L7, L8 and L10 glauconite separates by the different ultrasonic leaching experiments. The numbers at the bottom of each diagram refer to the different aliquots of each sample in Table 1. LOI stands for loss of ignition.

The previously released XRD diagrams of the untreated aliquots show the presence of two XRD peaks for the untreated L10 sample relative to the equivalent diagrams of the other samples (Figure 2). These two peaks are located at $19.2^{\circ}$ and $36.6^{\circ}(2 \theta)$ on a fuzzy diagram that was copied from Keppens [14]. Occurring only in the diagram of the untreated L10 sample, their absence in the other diagrams suggests the presence of a mineral that was dissolved by the dilute-acid leaching. The two theoretical mineral compositions that correspond to the location of these peaks, and to their relative intensities, are the $\mathrm{Na}-\mathrm{Mg}$ sulfate blödite $\left(\mathrm{Na}_{2} \mathrm{Mg}\left(\mathrm{SO}_{4}\right)_{2}, 4 \mathrm{H}_{2} \mathrm{O}\right)$ and the Fe sulfate rozenite $\left(\mathrm{Fe}\left(\mathrm{SO}_{4}\right)\right.$, 
$4 \mathrm{H}_{2} \mathrm{O}$ ). Combining this identification with the above chemical analyses of the untreated and HAc leached L10 sample, the Na content decreased dramatically due to leaching, while that of $\mathrm{Mg}$ remained in its analytical uncertainty and that of Fe increased. Therefore, blödite seems to be the additional mineral of marine origin [23] that apparently crystallized within the glauconite pellets.

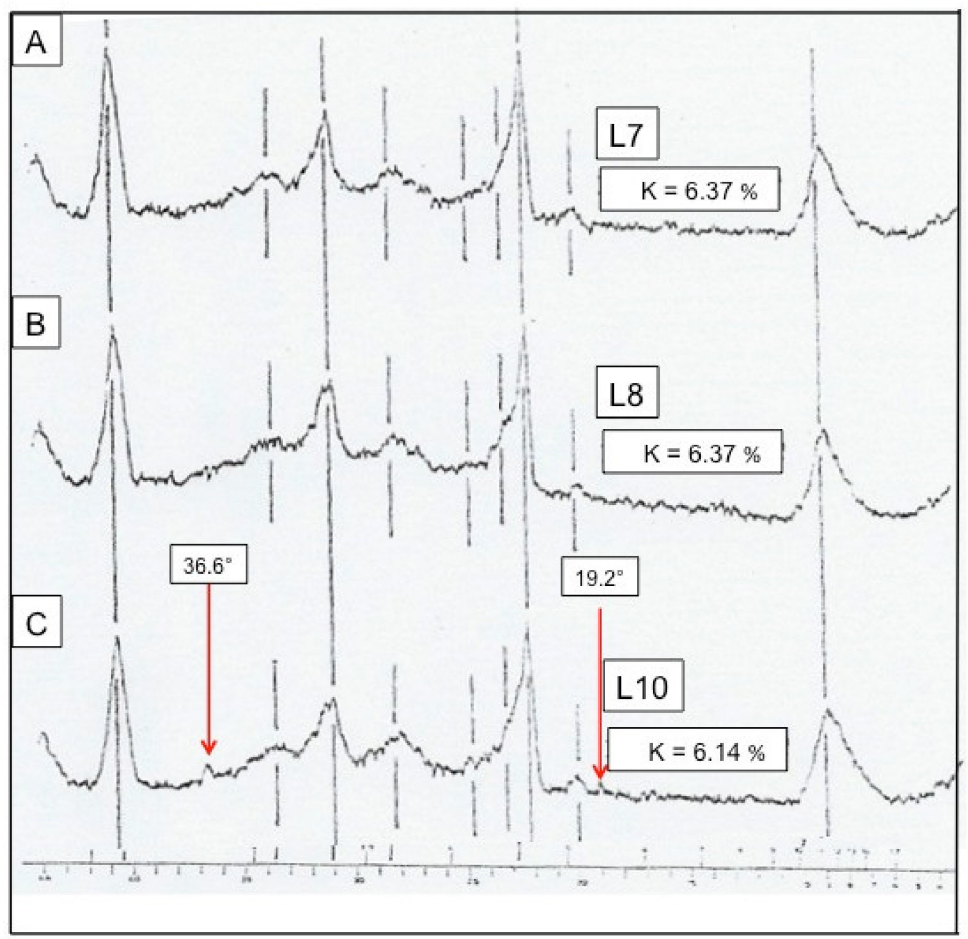

Figure 2. Copies of the original XRD diagrams of the three untreated glauconite fractions from Keppens [14]. The three diagrams A, B and C for the three samples L7, L8 and L10 are somehow fuzzy but show clearly the two peaks of the blödite mineral in the L10 sample located by the two red arrows.

In summary, the total contents of most major elements from differently treated separates relative to the untreated counterparts remained fairly stable, while the loss on ignition increased significantly from about $12 \%$ to $39 \%$. In fact, the increasing loss on ignition supports the fact that soluble mineral phases were quite systematically dissolved. In addition, the overall chemical compositions of the samples do not appear to have been uniform, as would be expected, with various elements removed to variable extents by the combined treatments. For instance, the $\mathrm{K}_{2} \mathrm{O}$ content of sample L7 decreased significantly, i.e., by $3.9 \%$ upon the $\mathrm{HCl}$ ultrasonic treatment, while the two other samples yield increasing $\mathrm{K}_{2} \mathrm{O}$ content by 2.2 to $2.3 \%$. The elements present in small amounts, such as $\mathrm{CaO}, \mathrm{Mn}_{3} \mathrm{O}_{4}, \mathrm{TiO}_{2}$ and $\mathrm{Na}_{2} \mathrm{O}$, all yield large variations due to the treatments, but these variations correspond to small amounts and did, therefore, probably not imply important mineral changes except, obviously, for the $\mathrm{L} 10$ sample. The almost constant variations of $\mathrm{SiO}_{2}$ and $\mathrm{MgO}$ were most often within analytical uncertainty, while this is not the case for $\mathrm{Al}_{2} \mathrm{O}_{3}$, for instance, that decreased more in the samples L8 and L10 than in sample L7. The value of $\mathrm{Fe}_{2} \mathrm{O}_{3}$ increased in sample L7 from untreated material to strongest shaking counterpart, but were very constant in those of the L8 and L10 samples

\subsection{The Variations of the Trace Elements}

The $\mathrm{Rb}$ content varied in the treated separates within the admitted $\pm 5 \%$ analytical uncertainty (Table 2A,B). In contrast, $96.1 \%$ of the Sr content were removed after the $\mathrm{HCl}$ treatment in sample L7, 91.5\% in sample L8 and 56.4\% in sample L10: Sr is clearly carried mostly by soluble minerals. Not analyzed for the untreated L7 sample, the content 
of the other trace elements were only discussed further for the aliquots after the HAc ultrasonic treatment.

Table 2. (A) Contents in trace elements of the untreated and leached glauconite pellets; (B) Variations in the contents in trace elements of the leached separates relative to the untreated reference sample.

\begin{tabular}{|c|c|c|c|c|c|c|c|c|c|c|c|c|}
\hline \multicolumn{13}{|c|}{ (A) } \\
\hline Sample IDs & $\begin{array}{c}\mathbf{R b} \\
(\mu \mathrm{g} / \mathrm{g})\end{array}$ & $\begin{array}{c}\mathrm{Sr} \\
(\mu \mathrm{g} / \mathrm{g})\end{array}$ & $\begin{array}{c}\mathrm{Ba} \\
(\mu \mathrm{g} / \mathrm{g})\end{array}$ & $\begin{array}{c}\mathrm{V} \\
(\mu \mathrm{g} / \mathrm{g})\end{array}$ & $\begin{array}{c}\mathrm{Ni} \\
(\mu \mathrm{g} /)\end{array}$ & $\begin{array}{c}\text { Co } \\
(\mu \mathrm{g} / \mathrm{g})\end{array}$ & $\begin{array}{c}\mathrm{Cr} \\
(\mu \mathrm{g} /)\end{array}$ & $\begin{array}{c}\mathrm{Zn} \\
(\mu \mathrm{g} / \mathrm{g})\end{array}$ & $\begin{array}{c}\mathrm{Cu} \\
(\mu \mathrm{g} /)\end{array}$ & $\begin{array}{c}\mathrm{Sc} \\
(\mu \mathrm{g} / \mathrm{g})\end{array}$ & $\begin{array}{c}\mathrm{Y} \\
(\mu \mathrm{g} / \mathrm{g})\end{array}$ & $\begin{array}{c}\mathrm{Zr} \\
(\mu \mathrm{g} / \mathrm{g})\end{array}$ \\
\hline L7 untreated $(=1)$ & 222 & 28.7 & & & & & & & & & & \\
\hline $\mathrm{US}+\mathrm{H}_{2} \mathrm{O} 20^{\prime}(=2)$ & 231 & 24.6 & 11.0 & 129 & 113 & 15.0 & 174 & 108 & 7.00 & 10.5 & 9.00 & 22.0 \\
\hline $\mathrm{US}+\mathrm{HAc} 20^{\prime}(=3)$ & & 14.0 & 8.00 & 131 & 107 & 14.0 & 190 & 86.0 & 4.00 & 11.0 & 8.00 & 26.0 \\
\hline $\mathrm{US}+\mathrm{HCl} 20^{\prime}(=4)$ & 230 & 3.03 & 8.00 & 129 & 112 & 14.0 & 199 & 80.0 & 5.00 & 9.50 & 2.00 & 22.0 \\
\hline $\mathrm{US}+\mathrm{HCl} 60^{\prime}(=5)$ & 231 & 5.34 & 7.00 & 129 & 111 & 13.0 & 194 & 80.0 & 5.00 & 10.5 & 2.00 & 25.0 \\
\hline $\mathrm{US}+\mathrm{H}_{2} \mathrm{O}+\mathrm{US}+\mathrm{HAc}(=6)$ & & 15.0 & 6.00 & 126 & 109 & 15.0 & 174 & 95.0 & 12.0 & 10.0 & 8.00 & 20.0 \\
\hline L8 untreated $(=1)$ & 226 & 35.1 & 17.0 & 128 & 115 & 15.0 & 208 & 93.0 & 5.00 & 10.5 & 7.00 & 33.0 \\
\hline $\mathrm{US}+\mathrm{H}_{2} \mathrm{O} 20^{\prime}(=2)$ & 230 & 26.0 & & & & & & & & & & \\
\hline $\mathrm{US}+\mathrm{HAc} 20^{\prime}(=3)$ & 227 & 20.2 & 5.00 & 130 & 117 & 11.0 & 197 & 84.0 & 4.00 & 10.5 & 7.00 & 28.0 \\
\hline $\mathrm{US}+\mathrm{HCl} 20^{\prime}(=4)$ & 225 & 4.43 & 7.00 & 135 & 113 & 16.0 & 175 & 79.0 & 3.00 & 9.50 & 2.00 & 22.0 \\
\hline $\mathrm{US}+\mathrm{H}_{2} \mathrm{O} 60^{\prime}(=5)$ & & 3.00 & 6.00 & 131 & 30.0 & 17.0 & 169 & 74.0 & bdl & 10.5 & bdl & 24.0 \\
\hline $\mathrm{US}+\mathrm{H}_{2} \mathrm{O} 24 \mathrm{~h}(=6)$ & & 3.00 & 7.00 & 135 & 37.0 & 14.0 & 173 & 74.0 & bdl & 10.0 & bdl & 24.0 \\
\hline L10 untreated $(=1)$ & 224 & 22.0 & 13.0 & 160 & 124 & 17.0 & 348 & 84.0 & 25.0 & 13.5 & 11.0 & 43.0 \\
\hline $\mathrm{US}+\mathrm{HAc} 20^{\prime}(=3)$ & 225 & 15.4 & & & & & & & & & & \\
\hline $\mathrm{US}+\mathrm{HCl} 20^{\prime}(=4)$ & 224 & 9.60 & 12.0 & 152 & 39 & 15.0 & 228 & 84.0 & 10.0 & 11.5 & 9.00 & 75.0 \\
\hline $\mathrm{US}+\mathrm{H}_{2} \mathrm{O}+\mathrm{US}+\mathrm{HAc}(=5)$ & & 16.0 & 11.0 & 139 & 110 & 16.0 & 235 & 91.0 & 15.0 & 11.5 & 9.00 & 75.0 \\
\hline $\mathrm{US}+\mathrm{H}_{2} \mathrm{O}+\mathrm{US}+\mathrm{HAc}(2 \times)(=6)$ & & 14.0 & 9.00 & 134 & nd & 16.0 & nd & 67.0 & 13.0 & 12.0 & 10.0 & 35.0 \\
\hline \multicolumn{13}{|c|}{ (B) } \\
\hline Sample IDs & $\begin{array}{l}\mathbf{R b} \\
(\%)\end{array}$ & $\begin{array}{c}\mathrm{Sr} \\
(\%)\end{array}$ & $\begin{array}{c}\mathrm{Ba} \\
(\%)\end{array}$ & $\begin{array}{c}\mathrm{V} \\
(\%)\end{array}$ & $\begin{array}{c}\mathrm{Ni} \\
(\%)\end{array}$ & $\begin{array}{l}\text { Co } \\
(\%)\end{array}$ & $\begin{array}{l}\mathrm{Cr} \\
(\%)\end{array}$ & $\begin{array}{l}\mathrm{Zn} \\
(\%)\end{array}$ & $\begin{array}{l}\mathrm{Cu} \\
(\%)\end{array}$ & $\begin{array}{c}\text { Sc } \\
(\%)\end{array}$ & $\begin{array}{c}Y \\
(\%)\end{array}$ & $\begin{array}{l}\mathrm{Zr} \\
(\%)\end{array}$ \\
\hline L7 untreated $(=1)$ & 0 & 0 & & & & & & & & & & \\
\hline $\mathrm{US}+\mathrm{H}_{2} \mathrm{O} 20^{\prime}(=2)$ & +4.1 & -14.6 & & 0 & 0 & 0 & 0 & 0 & 0 & 0 & 0 & 0 \\
\hline $\mathrm{US}+\mathrm{HAc} 20^{\prime}(=3)$ & & -51.2 & & +1.6 & -5.3 & -6.7 & +9.2 & -20.4 & -42.9 & +4.8 & -11.1 & +18.2 \\
\hline $\mathrm{US}+\mathrm{HCl} 20^{\prime}(=4)$ & +3.6 & -96.1 & & 0 & -0.9 & -6.7 & +14.4 & -25.9 & -28.6 & -9.5 & -77.8 & 0 \\
\hline $\mathrm{US}+\mathrm{HCl} 60^{\prime}(=5)$ & +4.1 & -81.4 & & 0 & -1.8 & -13.3 & +11.5 & -25.9 & -28.6 & 0 & -77.8 & +13.6 \\
\hline US $\mathrm{H}_{2} \mathrm{O}+$ US HAc $(=6)$ & & -47.7 & & -1.6 & -3.5 & 0 & 0 & -12.0 & +71.4 & -4.8 & -11.1 & -9.1 \\
\hline L8 untreated $(=1)$ & 0 & 0 & 0 & 0 & 0 & 0 & 0 & 0 & 0 & 0 & 0 & 0 \\
\hline $\mathrm{US}+\mathrm{H}_{2} \mathrm{O} 20^{\prime}(=2)$ & +1.8 & -25.9 & & & & & & & & & & \\
\hline $\mathrm{US}+\mathrm{HAc} 20^{\prime}(=3)$ & +0.4 & -42.5 & -70.6 & +1.6 & +1.7 & -26.7 & -5.3 & -9.7 & -20.0 & 0 & 0 & -15.2 \\
\hline $\mathrm{US}+\mathrm{HCl} 20^{\prime}(=4)$ & +0.1 & -87.4 & -58.8 & +5.5 & -1.7 & +6.6 & -15.9 & -15.1 & -40.0 & 9.5 & -71.4 & -33.3 \\
\hline $\mathrm{US}+\mathrm{H}_{2} \mathrm{O} 60^{\prime}(=5)$ & & -91.5 & -64.7 & +2.3 & -73.9 & +13.3 & -18.8 & -20.4 & bdl & 0 & bdl & -27.3 \\
\hline $\mathrm{US}+\mathrm{H}_{2} \mathrm{O} 24 \mathrm{~h}(=6)$ & & -91.5 & -58.8 & +5.5 & -67.8 & -6.7 & -16.8 & -20.4 & bdl & -4.8 & bdl & -27.3 \\
\hline L10 untreated $(=1)$ & 0 & 0 & 0 & 0 & 0 & 0 & 0 & 0 & 0 & 0 & 0 & 0 \\
\hline US + HAc 20' $(=3)$ & +0.4 & -30.0 & & & & & & & & & & \\
\hline $\mathrm{US}+\mathrm{HCl} 20^{\prime}(=4)$ & 0 & -56.4 & -7.7 & -5.0 & -68.5 & -11.8 & -34.5 & 0 & -60.0 & -17.4 & -18.2 & +74.4 \\
\hline $\mathrm{US} \mathrm{H}_{2} \mathrm{O}+\mathrm{US}$ HAc $(=5)$ & & -27.3 & -15.4 & -13.1 & -11.3 & -5.9 & -32.5 & +8.3 & -40.0 & -14.8 & -18.2 & +74.4 \\
\hline US $\mathrm{H}_{2} \mathrm{O}+$ US HAc $(2 \times)(=6)$ & & -36.4 & -30.8 & -16.3 & nd & -5.9 & nd & -20.2 & -48.0 & -8.9 & -9.1 & -18.6 \\
\hline
\end{tabular}

For the L8 and L10 samples that yield a complete spectrum of trace elements, the V content increased in sample L8, while it decreased in L10. The Ni content either remained within the analytical uncertainty such as in sample L7 or decreased significantly to about $70 \%$ in the two other untreated L7 and L8 references. Most Co, Sc and Y contents remained also within uncertainty with, however, significant $Y$ decreases in the L7 and L8 samples and a slight decrease for the $\mathrm{Cr}$ content after leaching. Decreases in $\mathrm{Cu}$ after acidic ultrasonic treatment are often significant, while $\mathrm{Zn}$ had a variable behavior: decreasing in sample L8 and increasing in sample L10 after treatment, probably due to the type(s) of dissolved minerals. In sample $\mathrm{L} 7$, the contents of $\mathrm{Co}, \mathrm{Zn}, \mathrm{Cu}$ and $\mathrm{Y}$ decreased significantly, while only that of $\mathrm{Cr}$ increased and that of $\mathrm{V}$ remained within analytical uncertainty. Furthermore, $\mathrm{Cu}$ decreased after leaching with dilute $\mathrm{HCl}(-60 \%)$, as well as $\mathrm{Sr}(-30 \%), \mathrm{Ni}(-68.5 \%)$ and $\mathrm{Cr}(-34.5 \%)$ in the untreated sample L10 hosting blödite.

In summary, amongst the analyzed trace elements, $\mathrm{Rb}, \mathrm{V}, \mathrm{Zn}$ and $\mathrm{Sc}$ seem not to have been affected by the combined ultrasonic and dilute acid leaching. Others, such as $\mathrm{Sr}, \mathrm{Ba}$, 
$\mathrm{Ni}, \mathrm{Co}, \mathrm{Cr}$ and $\mathrm{Cu}$ were systematically removed, while $\mathrm{Zr}$ behaved differently in the L8 relative to the L10 sample: it leached out from the former, while remaining in the latter.

\subsection{The K-Ar Data}

The K-Ar data obtained before and after the treatments were analytically equivalent for the L7 and L8 samples (Table 3). The average age values for both, at $18.0 \pm 0.4 \mathrm{Ma}$ and $19.1 \pm 0.4 \mathrm{Ma}$, are almost within uncertainty, while that of sample L10 is significantly higher at 22.1 $\pm 1.2 \mathrm{Ma}$. More precisely, the $\mathrm{K}-\mathrm{Ar}$ results display differently in a Harper [24] diagram for the radiogenic ${ }^{40} \mathrm{Ar}$ content relative to the corresponding $\mathrm{K}_{2} \mathrm{O}$ content (Figure 3A,B). The data points of the samples L7 and L8 move in opposite directions: those of the $\mathrm{L} 7$ aliquots yield increasing $\mathrm{K}_{2} \mathrm{O}$ content for a decreasing radiogenic ${ }^{40} \mathrm{Ar}$ content, while those of sample L8 move into the opposite direction. In the case of sample L10, the $\mathrm{H}_{2} \mathrm{O}$ treatment decreases the contents of both $\mathrm{K}_{2} \mathrm{O}$ and radiogenic ${ }^{40} \mathrm{Ar}$, whereas the $\mathrm{HAc}$ and $\mathrm{HCl}$ treatments increase the radiogenic ${ }^{40} \mathrm{Ar}$ content for similar $\mathrm{K}_{2} \mathrm{O}$ content.

Table 3. K-Ar data of the untreated and leached glauconite pellets.

\begin{tabular}{|c|c|c|c|c|c|c|}
\hline Sample IDs & $\mathrm{K}_{2} \mathrm{O}$ & ${ }^{40} \mathrm{Ar} *$ & $\operatorname{rad}{ }^{40} \mathrm{Ar}$ & ${ }^{40} \mathrm{Ar} /{ }^{36} \mathrm{Ar}$ & ${ }^{40} \mathrm{~K} / /^{36} \mathrm{Ar}$ & Age \\
\hline & $(\%)$ & $(\%)$ & $\left(10^{-6} \mathrm{~cm}^{3} / \mathrm{g}\right)$ & & $\left(\times 10^{-6}\right)$ & $(\mathrm{Ma}+/-2 \sigma)$ \\
\hline L7 untreated (=1) & 7.24 & 63.03 & 4.33 & 799.3 & 466.6 & $18.4(0.6)$ \\
\hline $\mathrm{US}+\mathrm{H}_{2} \mathrm{O} 20^{\prime}(=2)$ & 7.34 & 57.66 & 4.41 & 696.4 & 356.2 & $18.5(0.7)$ \\
\hline $\mathrm{US}+\mathrm{HAc} 20^{\prime}(=3)$ & 7.33 & 66.33 & 4.12 & 877.6 & 572.3 & $17.3(0.6)$ \\
\hline $\mathrm{US}+\mathrm{HCl} 20^{\prime}(=4)$ & 7.52 & 66.39 & 4.31 & & & $17.7(0.6)$ \\
\hline L8 untreated $(=1)$ & 7.37 & 62.77 & 4.49 & 793.7 & 453.7 & $18.8(0.6)$ \\
\hline $\mathrm{US}+\mathrm{H}_{2} \mathrm{O} 20^{\prime}(=2)$ & 7.29 & 70.99 & 4.43 & 1018.6 & 660.0 & $18.7(0.6)$ \\
\hline $\mathrm{US}+\mathrm{HAc} 20^{\prime}(=3)$ & 7.31 & 67.94 & 4.61 & 921.7 & 549.6 & $19.4(0.6)$ \\
\hline $\mathrm{US}+\mathrm{HCl} 20^{\prime}(=4)$ & 7.19 & 57.74 & 4.57 & & & $19.6(0.7)$ \\
\hline L10 untreated $(=1)$ & 7.14 & 67.59 & 5.08 & & & $21.9(0.7)$ \\
\hline $\mathrm{US}+\mathrm{H}_{2} \mathrm{O} 20^{\prime}(=2)$ & 7.25 & 73.84 & 4.88 & & & $20.7(0.7)$ \\
\hline $\mathrm{US}+\mathrm{HAc} 20^{\prime}(=3)$ & 7.12 & 64.31 & 5.23 & 828.0 & 385.4 & $22.7(0.8)$ \\
\hline $\mathrm{US}+\mathrm{HCl} 20^{\prime}(=4)$ & 7.12 & 72.28 & 5.37 & & & $23.1(0.7)$ \\
\hline
\end{tabular}

$(*$ radiogenic $)$

The obtained data points of the different aliquots display the same changes in a $\mathrm{K}-\mathrm{Ar}$ isochron diagram (Figure 1): those of samples L7 and L8 move in opposite directions, whereas the $\mathrm{H}_{2} \mathrm{O}$ leachate of the L10 aliquot yields a significant decrease in the age value due to an increase in the $\mathrm{K}_{2} \mathrm{O}$ content. In turn, the $\mathrm{K}$-Ar data reflect the various contents of the major elements, namely the three glauconite samples are not identical in their chemical composition and, therefore, not in their mineralogical composition, due to the presence of contaminant minerals. In the case of sample L10, the dissolution of a soluble mineral from untreated aliquot, even after a preliminary routine $\mathrm{H}_{2} \mathrm{O}$ treatment, modified the $\mathrm{Rb}-\mathrm{Sr}$ data, which is unusual e.g., [25]. Such behavior is most probably due to the dissolution of a mineral rich in $\mathrm{Sr}$ and depleted in $\mathrm{Rb}$ and $\mathrm{K}$.

\subsection{The Impact of the Duration of the Ultrasonic Shaking}

Variations in the $\mathrm{Rb}-\mathrm{Sr}$ isotopic ages of the glauconite pellets studied here by the $\mathrm{K}-\mathrm{Ar}$ method were addressed before by Pasteels et al. [6] by varying the duration of the ultrasonic shaking on three more samples not studied here (L1, L2 and L3 on Table 4 of Pasteels et al. [6]) from 20 to $60 \mathrm{~min}$, and even up to $24 \mathrm{~h}$ in the case of sample L8, all with the same reagent. In the case of the $\mathrm{Rb}-\mathrm{Sr}$ ages, longer ultrasonic treatments induced older ages for the L7 and L8 samples (Table 4). Related to these age increases are a slight increase in the Rb content in sample L7 and a slight decrease in L8, as well as a large increase in $\mathrm{Sr}$ in both samples. Furthermore, the systematic increase in radiogenic ${ }^{87} \mathrm{Sr}$ should be mentioned. These changes explain the variations in the ages, while the limited variations in the $\mathrm{Rb}$ content exclude any impact on the alkali-carrier minerals. 

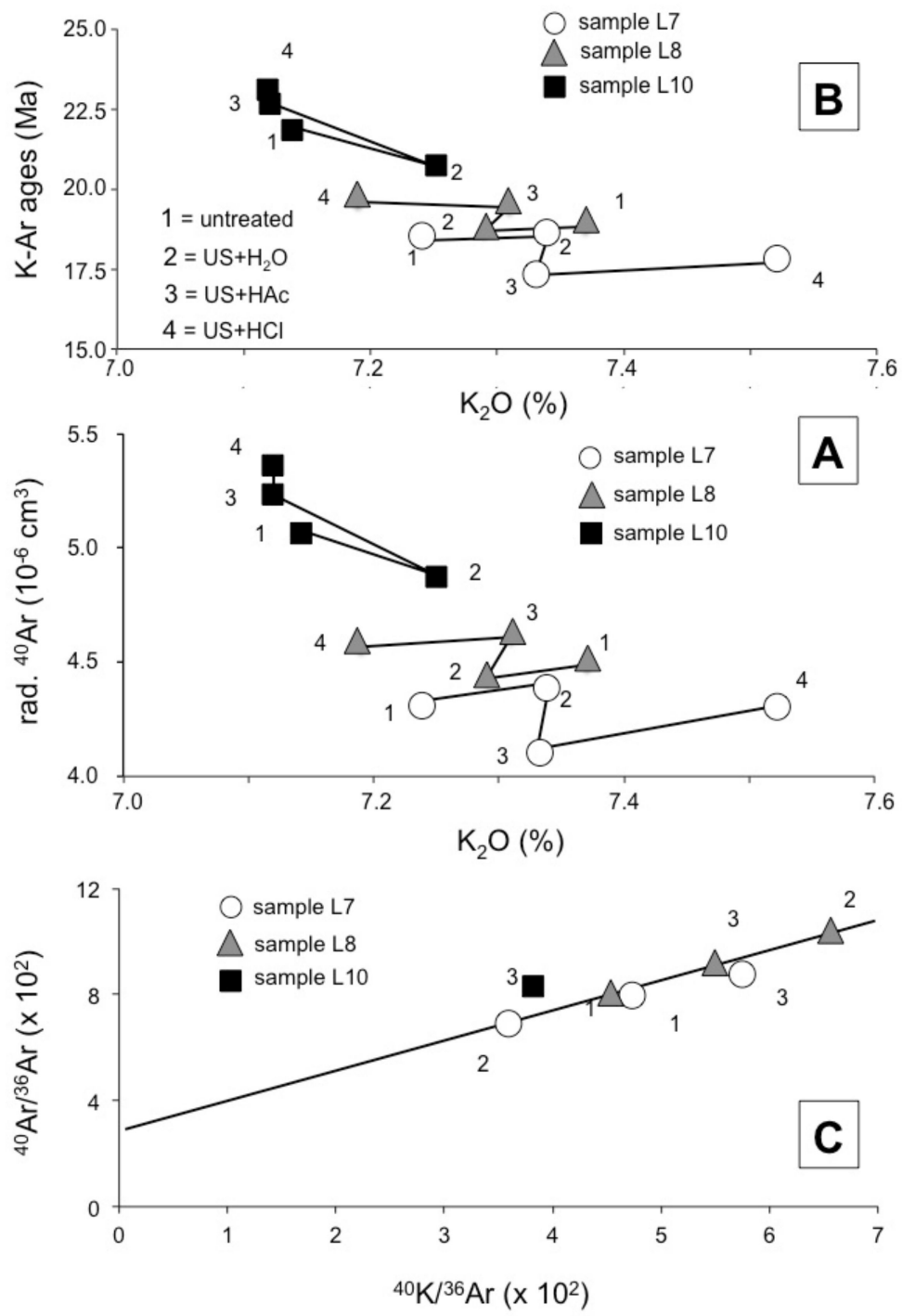

Figure 3. (A) Diagram displaying the content of radiogenic ${ }^{40} \mathrm{Ar}$ relative to $\mathrm{K}_{2} \mathrm{O}$ in the untreated and leached glauconite separates; (B) the same for the $\mathrm{K}-\mathrm{Ar}$ age values (in Ma) relative to the $\mathrm{K}_{2} \mathrm{O}$ content; (C) ${ }^{40} \mathrm{Ar} /{ }^{36} \mathrm{Ar}$ vs. ${ }^{40} \mathrm{~K} /{ }^{36} \mathrm{Ar}$ isochron diagram of the untreated and leached glauconite separates.

Increasing the shaking from 20 to $60 \mathrm{~min}$ in $\mathrm{HCl}$ only significantly reduced the contents in $\mathrm{TiO}_{2}$ and $\mathrm{K}_{2} \mathrm{O}$, while shaking sample $\mathrm{L} 8$ in $\mathrm{H}_{2} \mathrm{O}$ for $20 \mathrm{~min}$ and $60 \mathrm{~min}$, or for $24 \mathrm{~h}$ did not affect the contents of any of the main major elements. Only those of $\mathrm{Mn}_{3} \mathrm{O}_{4}, \mathrm{TiO}_{2}$ and $\mathrm{Na}_{2} \mathrm{O}$ decreased and increased again. Subjected to a duplicate treatment consisting first of a regular 20 min long shaking in $\mathrm{H}_{2} \mathrm{O}$ and then in $\mathrm{HAc}$, followed by a second treatment in $\mathrm{H}_{2} \mathrm{O}$, the $\mathrm{Al}_{2} \mathrm{O}_{3}, \mathrm{Mg}_{2} \mathrm{O}_{3}, \mathrm{CaO}$ and $\mathrm{TiO}_{2}$ contents of sample $\mathrm{L} 10$ decreased beyond analytical uncertainty, while those of $\mathrm{Mn}_{3} \mathrm{O}_{4}$ and $\mathrm{Na}_{2} \mathrm{O}$ increased, also beyond the analytical uncertainty. In the case of the trace elements, most variations in their contents induced by increased shaking time were limited within analytical uncertainties. Only the $\mathrm{Sr}$ and $\mathrm{Zn}$ contents visibly increased in sample L7 when the duration of the shaking in $\mathrm{HCl}$ increased from 20 to $60 \mathrm{~min}$. When the shaking time increased from 20 min to $24 \mathrm{~h} \mathrm{in} \mathrm{H}_{2} \mathrm{O}$, the $\mathrm{Ni}$ content decreased and that of Co increased in sample L8. When 20 min shaking in $\mathrm{H}_{2} \mathrm{O}$ was followed by another 20 min shaking in $\mathrm{HAc}$, the contents of $\mathrm{Sr}, \mathrm{Ba}, \mathrm{Zn}, \mathrm{Cu}$ and $\mathrm{Zr}$ decreased beyond analytical uncertainty. In summary, only shaking in $\mathrm{H}_{2} \mathrm{O}$ followed by an identical shaking duration in HAc had some leaching impact on the trace elements, obviously on a mineral carrier of the trace metals. 
Table 4. Report of the $\mathrm{Rb}-\mathrm{Sr}$ data of the untreated and leached glauconite pellets by Pasteels et al. [6]). The * stands for radiogenic and the $\mathrm{i}$ for initial ratio that corresponds to the seawater ratio at the syn-deposition time of glauconite crystallization.

\begin{tabular}{|c|c|c|c|c|c|c|}
\hline Sample IDs & $\mathbf{R b}$ & $\mathrm{Sr}$ & ${ }^{87} \mathrm{Sr} *$ & ${ }^{87} \mathrm{Rb} /{ }^{86} \mathrm{Sr}$ & ${ }^{87} \mathrm{Sr} /{ }^{86} \mathrm{Sr}$ & Age $(+/-2 \sigma)$ \\
\hline & $(\mu \mathrm{g} / \mathrm{g})$ & $(\mu \mathrm{g} / \mathrm{g})$ & $(+/-1 \%)$ & & $\left(+/-10^{-5}\right)$ & $(\mathrm{i}=0.7086)$ \\
\hline L7 untreated $(=1)$ & 222 & 28.7 & $18.5(1.0)$ & 22.42 & $0.7151(4)$ & $20.3(1.5)$ \\
\hline US $\mathrm{H}_{2} \mathrm{O} 20^{\prime}(=2)$ & 231 & 24.6 & $17.6(1.5)$ & 27.22 & $0.7159(7)$ & $18.8(2.2)$ \\
\hline US HCl 20' (=4) & 230 & 3.03 & $16.7(0.5)$ & 220.1 & 0.7649 (17) & $18.1(0.6)$ \\
\hline US HCl $60^{\prime}(=5)$ & 231 & 5.34 & $18.3(0.3)$ & 125.4 & $0.7436(5)$ & $19.7(0.6)$ \\
\hline L8 untreated $(=1)$ & 226 & 35.1 & $23.0(1.2)$ & 18.67 & $0.7152(3)$ & $25.0(1.9)$ \\
\hline $\mathrm{US} \mathrm{H}_{2} \mathrm{O} 20^{\prime}(=2)$ & 230 & 26.0 & $16.9(0.6)$ & 25.64 & $0.7151(2)$ & $18.3(1.2)$ \\
\hline duplicate & & & & & $0.7151(2)$ & \\
\hline US HAc $20^{\prime}(=3)$ & 227 & 20.2 & $17.5(0.4)$ & 32.53 & $0.7174(2)$ & $18.8(0.7)$ \\
\hline US $\mathrm{HCl} 20^{\prime}(=4)$ & 225 & 4.43 & $17.4(0.2)$ & 147.2 & $0.7482(4)$ & $18.9(0.5)$ \\
\hline US HCl 60' (=5) & 228 & 5.86 & $18.7(1.0)$ & 112.8 & $0.7411(14)$ & $20.7(1.6)$ \\
\hline US HCl 24h (=6) & 227 & 4.20 & $18.5(0.3)$ & 156.7 & $0.7534(6)$ & $20.1(0.6)$ \\
\hline L10 untreated $(=1)$ & 224 & 54.9 & $38.6(0.4)$ & 11.83 & $0.7157(8)$ & $42.1(1.6)$ \\
\hline US HAc $20^{\prime}(=3)$ & 225 & 15.4 & $22.3(1.0)$ & 42.36 & $0.7232(6)$ & $24.2(1.3)$ \\
\hline US $\mathrm{HCl} 20^{\prime}(=4)$ & 224 & 9.60 & $26.1(0.6)$ & 67.64 & $0.7363(3)$ & $28.7(1.1)$ \\
\hline
\end{tabular}

The K-Ar method was not applied to variably shaken aliquots but only during 20 min with $\mathrm{H}_{2} \mathrm{O}, \mathrm{HAc}$ and $\mathrm{HCl}$. The age increased the most in the case of the $\mathrm{HCl}$ interaction for the L8 and L10 samples, while it decreased about the same for sample L7.

\section{Discussion}

The elemental and $\mathrm{K}-\mathrm{Ar}$ isotopic data obtained here raise a concern about the mineralogical homogeneity of glauconite samples collected within a narrow neighborhood, as the pellets apparently also carried accessory mineral phases. The treated aliquots of the L8 and L10 samples yield opposite K-Ar and elemental trends, suggesting at least different impacts by the leaching/shaking tests. For instance, the systematical leaching of Na by all treatments points to the occurrence of a constitutive soluble phase easily removed by whichever treatment and identified to be blödite detected in sample L10 by XRD. Some Na content could also or additionally have resulted as part of halite $\mathrm{NaCl}$ crystallized from the evaporation of seawater that could have diffused into the growing authigenic glauconite pellets during crystallization, while blödite is a reasonable alternative, contemporaneously or after the crystallization of the glauconite pellets. In contrast, $\mathrm{Fe}_{2} \mathrm{O}_{3}$ does not appear to have contributed significantly as its content only decreased significantly in the aliquots of sample L7, whereas it appeared quite uniform in most of those from the L8 and L10 samples. The systematic increases of the loss on ignition also alerts for discrete changes in the mineral compositions of the three samples. The high initial $\mathrm{K}$-Ar age value of sample L10 and its slight increase after interaction with dilute acids also suggest the occurrence of various minerals dispersed in the pellets together with glauconite.

\subsection{About the Earlier Published Rb-Sr Data}

The $\mathrm{Rb}-\mathrm{Sr}$ results published by Pasteels et al. [6] were plotted again here into an isochron diagram (Figure 4A) where the data points fit roughly with a straight array except that of the untreated L10 aliquot that plots above the line. A closer look at the Rb and Sr contents shows that $\mathrm{Rb}$ is hardly affected by the different treatments since its contents range narrowly from $222 \mu \mathrm{g} / \mathrm{g}$ for the untreated A1 aliquot of sample L7 to $231 \mu \mathrm{g} / \mathrm{g}$ for the two aliquots of the $\mathrm{L} 7$ sample leached by $\mathrm{H}_{2} \mathrm{O}$ and $\mathrm{HCl}$. The difference of $+4.1 \%$ is clearly within the analytical uncertainty. The $\mathrm{Sr}$ content varies much more, i.e., from 3.0 to $54.9 \mu \mathrm{g} / \mathrm{g}$, suggesting that the applied experiments affected mostly, if not only, Sr carrying minerals. A further interesting relationship concerns the $\mathrm{Sr}$ contents and the ${ }^{87} \mathrm{Sr} /{ }^{86} \mathrm{Sr}$ ratios from leached residues (Figure 4B). The $\mathrm{H}_{2} \mathrm{O}$ leaching with an ultrasonic shaking only slightly 
reduces the $\mathrm{Sr}$ content and does not affect the ${ }^{87} \mathrm{Sr} /{ }^{86} \mathrm{Sr}$ ratio. This suggests that the $\mathrm{H}_{2} \mathrm{O}$ treatment released only $\mathrm{Sr}$ from water-soluble minerals, such as the suspected salts with an ${ }^{87} \mathrm{Sr} /{ }^{86} \mathrm{Sr}$ ratio of about $0.7154 \pm 0.0004(2 \sigma)$. Obviously the ultrasonic shaking did not add much, except probably that it enabled de-ionized $\mathrm{H}_{2} \mathrm{O}$ to reach mineral particles that were physically protected within the pellets. It is also plausible that the obtained ${ }^{87} \mathrm{Sr} /{ }^{86} \mathrm{Sr}$ ratio of about 0.7154 is not representative of the depositional environment of the glauconite pellets, but rather indicative of a post-depositional diagenetic impact that probably favored the crystallization and/or the protection of these suspected minerals with abnormally high $\mathrm{Sr}$ content and unexpected ${ }^{87} \mathrm{Sr} /{ }^{86} \mathrm{Sr}$ ratios. The additional HAc treatment leached about 40 to $70 \%$ of the Sr from the two aliquots of the L8 and L10 samples. It yielded an ${ }^{87} \mathrm{Sr} /{ }^{86} \mathrm{Sr}$ ratio from 0.7174 to 0.7232 , which is even above the ratio of 0.7154 for the previous $\mathrm{H}_{2} \mathrm{O}$ treatment. The removed $\mathrm{Sr}$ with a slightly higher ${ }^{87} \mathrm{Sr} /{ }^{86} \mathrm{Sr}$ ratio seems to have been carried mostly by minerals sensitive to the acidic leaching, but not to the ultrasonic shaking in $\mathrm{H}_{2} \mathrm{O}$. The $\mathrm{HCl}$ treatment removed more than $80 \%$ of the originally trapped $\mathrm{Sr}$ in the pellets, which resulted in an expectedly significant increase in the trapped ${ }^{87} \mathrm{Sr} /{ }^{86} \mathrm{Sr}$ ratio of the residues from 0.7363 to 0.7534 . In turn, the ultrasonic shaking did visibly not increase the amount of removed Sr, while an increase in the reagent's acidity appeared to be more efficient in this respect. Another fact to be noticed is about the correlation between Sr contents and ${ }^{87} \mathrm{Sr} /{ }^{86} \mathrm{Sr}$ ratios in the residues: as long as the $\mathrm{Sr}$ content is higher than $25 \mu \mathrm{g} / \mathrm{g}$, the ${ }^{87} \mathrm{Sr} /{ }^{86} \mathrm{Sr}$ ratios remain almost identical at $0.7154 \pm 0.0004$ (Figure $4 \mathrm{~B}$ ). When the Sr content ranges from about 25 to $6 \mu \mathrm{g} / \mathrm{g}$, the ${ }^{87} \mathrm{Sr} /{ }^{86} \mathrm{Sr}$ ratio increases progressively to about 0.7400 , and when its content drops below $6 \mu \mathrm{g} / \mathrm{g}$, the increase in the ${ }^{87} \mathrm{Sr} /{ }^{86} \mathrm{Sr}$ is even stronger. Notable is the fact that when the $\mathrm{Sr}$ content is high in the pellets, i.e., above $25 \mu \mathrm{g} / \mathrm{g}$, the contents of the additional carriers overwhelm those of the glauconite pellets. The Sr of the latter becoming dominant only when the content in the pellets is below $6 \mu \mathrm{g} / \mathrm{g}$. It can then not be excluded that the isochron of the sole glauconite pellets only includes the data points that fit the dashed line of the diagram with an initial ${ }^{87} \mathrm{Sr} /{ }^{86} \mathrm{Sr}$ ratio of about 0.715 (Figure 4B). This change would slightly lower the "stratigraphic" age, which may then no longer relate to the stratigraphic scale but result from the above-mentioned delayed diagenetic episode. In this case, the blödite-type and the other soluble minerals would have crystallized at the same time as the insoluble glauconite, with an identical initial ${ }^{87} \mathrm{Sr} /{ }^{86} \mathrm{Sr}$ ratio and an overwhelming Sr content.

The $\mathrm{Rb}-\mathrm{Sr}$ diagram plot somehow confirms this concept: with the exception of the data point of the $\mathrm{L} 10$ residue after $\mathrm{HCl}$ leaching/shaking, all others plot along an array that may also be considered to be an isochron (full line in Figure 4A). The four L7 data points fit a first plausible isochron (full line in Figure 4A) with an age of $18.1 \pm 3.1(2 \sigma) \mathrm{Ma}$, an initial ${ }^{87} \mathrm{Sr} /{ }^{86} \mathrm{Sr}$ ratio of $0.7095 \pm 0.0052(2 \sigma)$ and a MSWD of 13. The data points of the L8 untreated and residues plot along a sub-parallel isochron with an age of $19.6 \pm 1.8(2 \sigma) \mathrm{Ma}$, an initial ${ }^{87} \mathrm{Sr} /{ }^{86} \mathrm{Sr}$ ratio of $0.7089 \pm 0.0024(2 \sigma)$ and a higher MSWD of 63 . The obtained ages and initial ${ }^{87} \mathrm{Sr} /{ }^{86} \mathrm{Sr}$ ratios of these two isochrons overlap, while the data points of the third L10 sample are clearly above the two arrays. Beyond these differences, it appears that minerals that were solubilized by the weak acids, such as the blödite in sample L10 for instance, as well as other soluble minerals characteristic of reduced environments such as glauconite pellets, could have crystallized within the volume and the ambiance of the pellets.

It is, then interesting to compare these results with the contents of the major and trace elements depending on the used reagents to identify which kind of soluble minerals characterize either oxidizing or reducing environments in the pellets. Leaching sample L7 with $\mathrm{H}_{2} \mathrm{O}$ removed large amounts of $\mathrm{CaO}$. In the case of sample L8, the same $\mathrm{H}_{2} \mathrm{O}$ leaching removed mostly $\mathrm{Mn}_{3} \mathrm{O}_{4}$, while $\mathrm{HAc}$ leaching produced the highest removals of $\mathrm{Mn}_{3} \mathrm{O}_{4}$ and $\mathrm{CaO}$. In turn, high decreases were observed for $\mathrm{Na}_{2} \mathrm{O}, \mathrm{Mn}_{3} \mathrm{O}_{4}$ and $\mathrm{CaO}$ in the samples $\mathrm{L} 7$ and L8, whereas the highest losses in sample $\mathrm{L} 10$ were also in $\mathrm{Na}_{2} \mathrm{O}, \mathrm{Mn}_{3} \mathrm{O}_{4}$ and $\mathrm{CaO}$, suggesting the same dissolutions in the three samples at various amounts. 

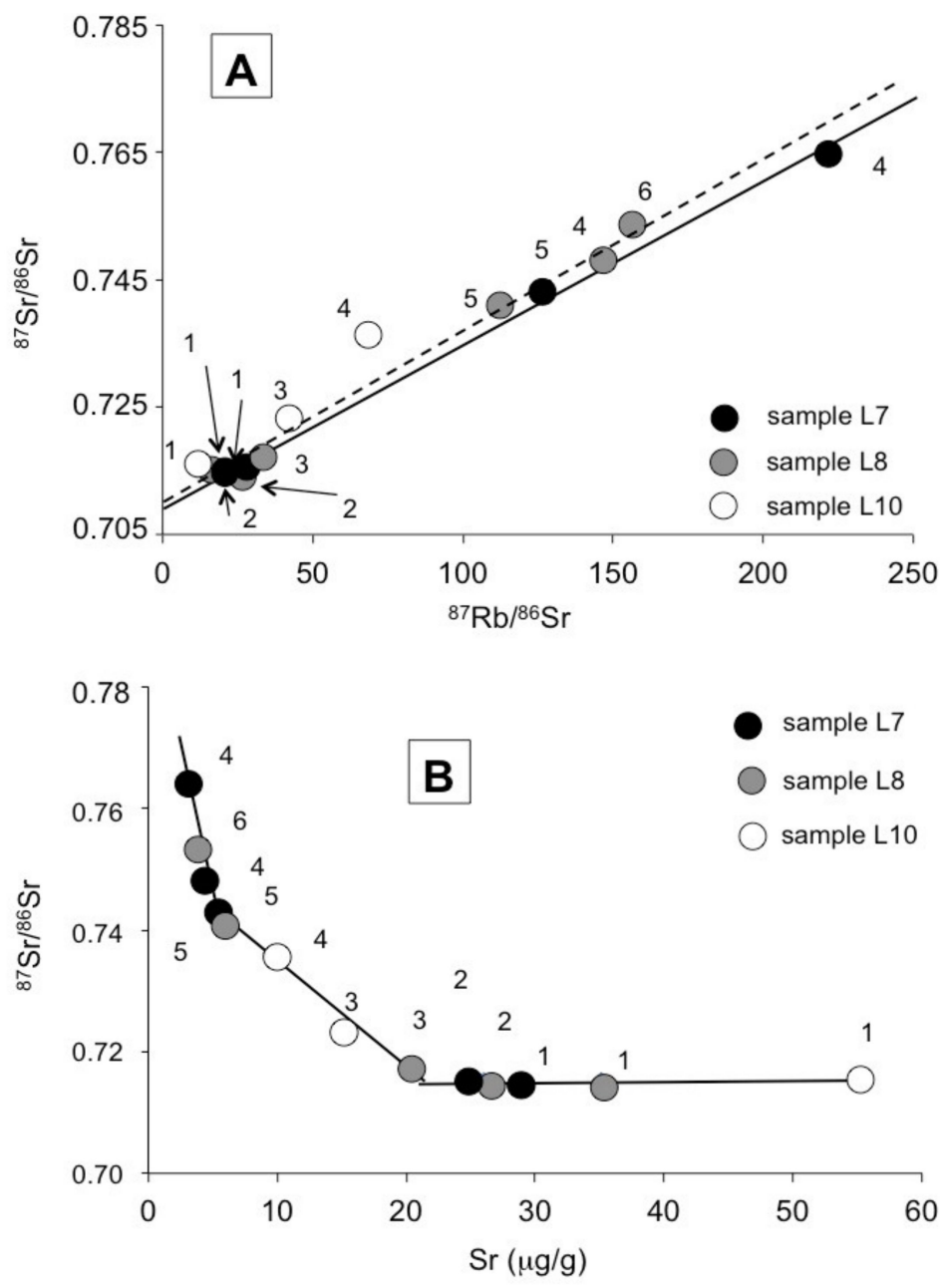

Figure 4. (A) Isochron diagram of the previously published $\mathrm{Rb}-\mathrm{Sr}$ data, the full line mostly includes the data points of sample L7 and the dashed line are those of sample L8 and some of sample L10; (B) Diagram of the ${ }^{87} \mathrm{Sr} /{ }^{86} \mathrm{Sr}$ ratios of the analyzed residues with their Sr content. In both diagrams, the samples yield symbols colored differently with a numbering of the individual leaching.

In summary, the glauconite pellets contained high amounts of foreign elements that were released by $\mathrm{H}_{2} \mathrm{O}$ and dilute acids, improved by ultrasonic shaking. The first conclusion is that the preparation used by Pasteels et al. [6], based on a magnetic enrichment and $\mathrm{H}_{2} \mathrm{O}$ rinsing, appears to have not been sufficient to remove the accessory mineral phases characterized especially by metal-rich components that have crystallized within the pellets, either at the same time as the glauconite crystals in the reduced microenvironment of the pellets, or afterwards during a further diagenesis and with a different ${ }^{87} \mathrm{Sr} /{ }^{86} \mathrm{Sr}$ ratio. The systematic leaching of high amounts of $\mathrm{Mn}_{3} \mathrm{O}_{4}$, of $\mathrm{TiO}_{2}$ and of less $\mathrm{Fe}_{2} \mathrm{O}_{3}$ in the leachates testifies for the occurrence of such metal-rich soluble components. Whereas $\mathrm{CaO}$ was leached quite systematically, it appears that here the soluble mineral(s) probably did not precipitate at the time the pellets crystallized, as its (their) ${ }^{87} \mathrm{Sr} /{ }^{86} \mathrm{Sr}$ ratio(s) is (are) different from that of the Middle Miocene (18 Ma) seawater, that was of 0.7087-0.7088 [26] This value is close to the value of 0.7086 used by Pasteels et al. [6] in Table 4 . The occurrence of $\mathrm{Na}_{2} \mathrm{O}$ in the leachates relates reasonably to the identified blödite that could have crystallized when the seawater dried out within the pellets. Blödite, known to carry high Sr contents, as determined here, could have been trapped within the pellets, which hid it during the initial contact with $\mathrm{H}_{2} \mathrm{O}$ during sample preparation. In turn, this specific mineral composition of the glauconite pellets affected only the $\mathrm{Rb}-\mathrm{Sr}$ and not the $\mathrm{K}-\mathrm{Ar}$ system, because they carry mostly $\mathrm{Sr}$ and $\mathrm{Na}$, but not $\mathrm{K}$ and $\mathrm{Rb}$. The bias in the $\mathrm{Rb}-\mathrm{Sr}$ age 
is then the consequence of the addition of $\mathrm{Sr}$ with an ${ }^{87} \mathrm{Sr} /{ }^{86} \mathrm{Sr}$ ratio different from that of the glauconite mineral that removed the data point away from initial isochron.

\subsection{Comparison of the K-Ar and the Previously Published Rb-Sr Data}

The $\mathrm{Rb}-\mathrm{Sr}$ data of Pasteels et al. [6] that were obtained on the same samples as the $\mathrm{K}-\mathrm{Ar}$ and geochemical data generated here (Table 4), outline a high $\mathrm{Rb}-\mathrm{Sr}$ age for the sole untreated L10 sample with a very high Sr content. It is clear that the difference is not due to an analytic aspect as the two other samples yield identical $\mathrm{Rb}-\mathrm{Sr}$ and $\mathrm{K}-\mathrm{Ar}$ ages. Clearly abnormal, the $\mathrm{Rb}-\mathrm{Sr}$ age spectra at $42.1 \pm 1.6,24.2 \pm 1.3$ and $28.7 \pm 1.1 \mathrm{Ma}$ for the three analyzed L10 aliquots with an initial ${ }^{87} \mathrm{Sr} /{ }^{86} \mathrm{Sr}$ ratio set conventionally at 0.7086 , are clearly above the corresponding $\mathrm{K}-\mathrm{Ar}$ values. These high values are also visible in the isochron diagram (Figure $4 \mathrm{~A}$ ), where the untreated aliquot has the lowest ${ }^{87} \mathrm{Rb} /{ }^{86} \mathrm{Sr}$ ratio of all analyzed aliquots, while plotting above the drafted isochron. In summary, the database points towards a specific mineral composition that clearly affects the $\mathrm{Rb}-\mathrm{Sr}$ system and not its $\mathrm{K}-$ Ar equivalent.

The $\mathrm{Rb}$ contents remain quite constant for the untreated and leached aliquots of sample L10, the difference needs to relate to the higher Sr content of the untreated sample, which reduces its $\mathrm{Rb} / \mathrm{Sr}$ ratio to a significant lower value than those of the other aliquots. This is also visible in the diagram that compares the ${ }^{87} \mathrm{Sr} /{ }^{86} \mathrm{Sr}$ ratios with the corresponding Sr content (Figure 4B). Interestingly, when ultrasonically leached, the L10 aliquots yield $\mathrm{Rb}-\mathrm{Sr}$ age data that are much younger, even within analytical uncertainty, than those of the $\mathrm{K}-\mathrm{Ar}$ data. In turn, as the differences between the $\mathrm{Rb}-\mathrm{Sr}$ and $\mathrm{K}-\mathrm{Ar}$ data of sample L10 obviously relate to the occurrence of blödite, a mineral enriched in $\mathrm{Sr}$ and lacking $\mathrm{K}$ and $\mathrm{Rb}$, in the untreated L10 aliquot. It can also be stated that the Rb-Sr data were not biased by the preparation or by any analytical aspect, but correspond to a mineral phase that was not removed during the sample preparation.

All obtained $\mathrm{Rb}-\mathrm{Sr}$ and $\mathrm{K}-\mathrm{Ar}$ data were combined into a chart that allows a straight comparison of the results (Figure 5). Relative to the stratigraphic reference, most age data are on the higher side by both the $\mathrm{Rb}-\mathrm{Sr}$ and $\mathrm{K}-\mathrm{Ar}$ methods. In detail, the untreated aliquot of sample L8 and all those of sample L10 yield higher age values than the stratigraphic reference. It is confirmed that the high age value of the untreated L10 aliquot is mostly due to the identified blödite with an impact on only the $\mathrm{Rb}-\mathrm{Sr}$ system. However, for that L10 sample, the data plots of the leached/shaken aliquots remain unevenly above the stratigraphic reference, which suggests that they also probably contain insoluble detrital components such as illite-type clay crystals that are clearly of detrital origin. The overall proposal for sample L10 is then that it was apparently deposited in a marine environment that was slightly different from that of the two other L7 and L8 samples in both its sedimentological and mineralogical context: more exposed to detrital supplies identified by further clay material and it also hosted a $\mathrm{Na}-\mathrm{Mg}$ sulfate.

\subsection{Evaluation of the Sample Preparation Techniques}

It is difficult to evaluate precisely the impact of the preparation on a limited number of results. Here, the age difference of the untreated aliquot of the L10 sample relative to those of its treated aliquots is due to the occurrence of blödite overwhelmingly loaded in $\mathrm{Sr}$ that did not affect the K-Ar data because it lacks alkali elements. This interpretation is supported by the homogeneous $\mathrm{K}-\mathrm{Ar}$ results of the four aliquots of this L10 sample that were subjected exactly to the same preparation steps as the equivalent aliquots of the two other samples. In the case of the two other L7 and L8 samples, the K-Ar ages also decreased after $\mathrm{HCl}$ reaction, which could be due to the dissolution, not of blödite but of another acid-sensitive soluble mineral and/or to the removal, by shaking the pellets in dilute acid, of detrital particles that were sticking to the glauconite crystals in the pellets. 


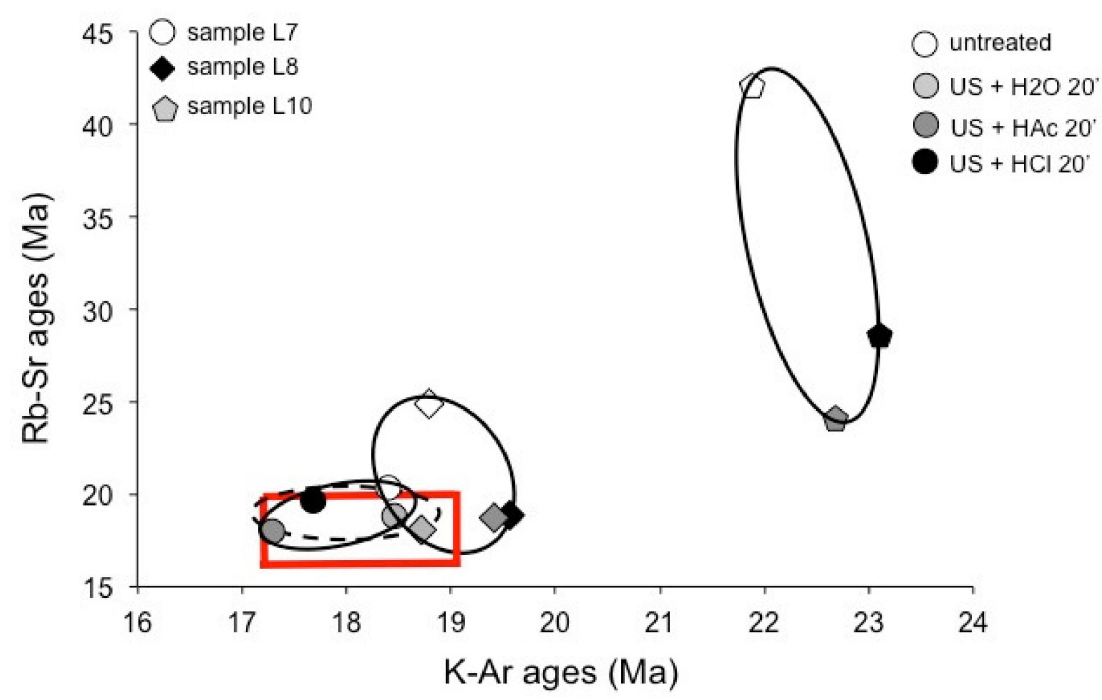

Figure 5. Synoptic chart of the Rb-Sr and K-Ar isotopic results of all L7, L8 and L10 glauconite aliquots. The red rectangle locates the stratigraphic age of the samples, each branch giving the analytical uncertainty for each method. The three full-lined circles integrate the data points of each sample, while the dashed-line circles identify the five data points within the stratigraphic age. The colored symbols to the right stand for all samples.

Leaching experiments with dilute $\mathrm{HCl}$ or $\mathrm{HAc}$ acids have been extensively used in isotopic dating of clay-type minerals as they dissolve carbonates, sulfates and oxides, while leaving the clay crystals unaffected e.g., [15]. Such dissolutions are visible here on the basis of the changing $\mathrm{CaO}$ and $\mathrm{Fe}_{2} \mathrm{O}_{3}$ contents, while additional ultrasonic shaking seems not to have modified the impact of the chemical interaction. Leaching of $\mathrm{Fe}_{2} \mathrm{O}_{3}$ indicates, together with that of the metallic trace elements, that metal-rich crystals were dissolved by the applied treatments, especially for sample L10 that also contained soluble Na- and Ca-rich crystals that crystallized in the reduced environment of the glauconite pellets. Ultrasonic shaking seems justified for disaggregating mineral agglomerates, which facilitates the removal of detrital grains or particles that are potentially trapped within glauconite pellets and might be difficult to reach with acidic solutions.

In summary, the above multi-method isotopic dating of glauconite pellets focuses on an aspect in their preparation that needs to be highlighted again: a leaching/cleaning of the pellets appears to be very necessary with dilute reagents such as HAc and/or HCl. In addition, in the case of pelleted crystals such as glauconite grains, the addition of ultrasonic shaking seems also justified to somehow disaggregate the pellets in order to facilitate the access of the aggregated pellets to the used reagents. Of course, this procedure is only a suggestion based on experimental data with open choices in the types of reagents and/or the duration of the interactions that can obviously be adjusted.

\section{Conclusions}

Authigenic glauconite pellets represent important historic references for the calibration of the time scale by $\mathrm{K}-\mathrm{Ar}$ and/or $\mathrm{Rb}-\mathrm{Sr}$ isotopic dating. As illite separates, they were often treated with different reagents such as dilute $\mathrm{HCl}$ and/or $\mathrm{HAc}$, but seldom together with ultrasonic shaking. The same procedure has been strictly applied again here for a comparison of $\mathrm{K}-\mathrm{Ar}$ dating of three samples previously dated by $\mathrm{Rb}-\mathrm{Sr}$ in order to precisely compare the two sets of data. Two opposite $\mathrm{K}-\mathrm{Ar}$ data trends for the elemental contents suggest various mineral compositions in the untreated pellets. The $\mathrm{K}-\mathrm{Ar}$ data obtained before and after the treatments are analytically similar for all aliquots of two of the analyzed samples, while those of the third one yield a slightly higher age difference. In fact, this sample also contains blödite identified by XRD, known as Sr enriched and for 
its marine origin, that affected the $\mathrm{Rb}-\mathrm{Sr}$ data and not the equivalent $\mathrm{K}-\mathrm{Ar}$ data. Based on its ${ }^{87} \mathrm{Sr} /{ }^{86} \mathrm{Sr}$ ratio above that of the depositional marine environment, this mineral appears to have crystallized during a late diagenetic episode relative to the glauconite precipitation. The chemical analyses show that the sample preparation has a determining impact on the isotopic dating of clay-type minerals. This technical aspect becomes especially important when glauconite isotopic dating is of stratigraphic application, by removing, or not, accessory minerals trapped in the pellets during initial crystallization or delayed diagenesis. It is essential to systematically leach the selected aliquots with dilute acid, run and, preferentially, compare the $\mathrm{Rb}-\mathrm{Sr}$ and $\mathrm{K}-\mathrm{Ar}$ data for a consolidated evaluation of the obtained ages. The combination of these two isotopic methods strengthen not only the isotopic and mineralogical results, but provides also information about the sedimentary context of the selected material.

Author Contributions: Conceptualization, N.C. and E.K.; formal analysis, E.K., I.T.U. and A.A.; methodology, N.C. All authors have read and agreed to the published version of the manuscript.

Funding: This research received no external funding.

Data Availability Statement: Data are available on request to the authors.

Acknowledgments: We would like to dedicate cordial thanks to the late Emeritus Professor Dr. Paul Pasteels for having allowed us to complete the Rb-Sr study of three glauconite separates by chemical and $\mathrm{K}-\mathrm{Ar}$ analyses that became the basis of the present study. Two of us, who knew him for years, would also like to dedicate this, as a token of appreciation, to a very gentle colleague and a highly-respected scientist. Two anonymous reviewers are also sincerely thanked for their remarks, corrections and suggestions that were very useful to improve this presentation. The editorial team is also thanked for efficiency and constant availability during the final proofing round.

Conflicts of Interest: The authors declare no conflict of interest.

\section{References}

1. Ehlmann, A.J.; Hulings, N.C.; Glover, E.D. Stages of glauconite formation in modern foraminiferal sediments. Sedim. Petrol. 1963, 33, 87-96.

2. Odin, G.S.; Matter, A. De glauconarium origine. Sedimentology 1981, 28, 611-641. [CrossRef]

3. Velde, B. Green clay minerals. In Treatise on Geochemistry 7. Sediments, Diagnosis and Sedimentary Rocks; Holland, H.D., Turekian, K.K., Eds.; Elsevier: Amsterdam, The Netherlands, 2004; Volume 7, pp. 309-324.

4. Cormier, R.F. Rubidium-Strontium ages of glauconite. Bull. Geol. Soc. Am. 1956, 67, 1812.

5. Thompson, G.R.; Hower, J. An explanation for low radiometric ages from glauconite. Geochim. Cosmochim. Acta 1973, 37, 1473-1491. [CrossRef]

6. Pasteels, P.; Laga, P.; Keppens, E. Essai d'application de la méthode radiométrique au strontium aux glauconies du Néogène: Le problème du traitement de l'échantillon avant analyse. Comptes Rendus Académie Des. Sci. 1976, 282, $2029-2032$.

7. Morton, J.P.; Long, L.E. Rb-Sr ages of glauconite recrystallization: Dating times of regional emergence above sea level. J. Sedim. Petrol. 1980, 54, 495-506.

8. Keppens, E.; Pasteels, P. A comparison of rubidium-strontium and potassium-argon apparent ages on glauconies. In Numerical Dating in Stratigraphy; Odin, G.S., Ed.; Wiley: New York, NY, USA, 1982; pp. 225-239.

9. Odin, G.S.; Dodson, M.H. Zero isotopic age of glauconies. In Numerical Dating in Stratigraphy; Odin, G.S., Ed.; Wiley: New York, NY, USA, 1982; pp. 277-306.

10. Foland, K.A.; Hubacher, F.A.; Arehartet, G.B. 40Ar/39Ar dating of very fine-grained samples: An encapsulated-vial procedure to overcome the problem of 39Ar recoil loss. Chem. Geol. Isot. Geosc. Sect. 1992, 102, 269-276.

11. Smith, P.E.; Evensen, N.M.; York, D. First successful 40Ar/39Ar dating of glauconites: Argon recoil in single grain cryptocrystalline material. Geology 1993, 21, 41-44. [CrossRef]

12. Clauer, N.; Huggett, J.M.; Hillier, S. How reliable is the K-Ar glauconite chronometer? A case study of Eocene sediments from the Isle of Wight. Clay Min. 2005, 40, 167-176. [CrossRef]

13. Odin, G.S.; Hunziker, J.C. Potassium-argon dating of washed, leached, weathered and reworked glauconies. In Numerical Dating in Stratigraphy; Odin, G.S., Ed.; J. Wiley: New York, NY, USA, 1982; pp. 363-385.

14. Keppens, E. Onderzoek van Het Glauconiet als Geochronometer voor de Rb-Sr Dateringsmethode. Ph.D. Thesis, Vrije Universiteit Brussel, Brussel, Belgium, 1981.

15. Clauer, N.; Chaudhuri, S.; Kralik, M.; Bonnot-Courtois, C. Effects of experimental leaching on Rb-Sr and K-Ar isotopic systems and REE contents of diagenetic illite. Chem. Geol. 1993, 103, 1-16. [CrossRef] 
16. Clauer, N.; Cocker, J.D.; Chaudhuri, S. Isotopic dating of diagenetic illites in reservoir sandstones: Influence of the investigator effect. In Origin, Diagenesis, and Petrophysics of Clay Minerals in Sandstones. Soc. Econ. Pal. Miner. Spec. Pub. 1992, 47, 5-12.

17. Berggren, W.A. A Cenozoic time-scale-Some implications for regional geology and paleobiogeography. Lethaia 1972, 5, 195-215. [CrossRef]

18. Samuel, J.; Rouault, R.; Besnus, Y. Analyse multi-élémentaire standardisée des matériaux géologiques en spectrométrie d'émission par plasma à couplage inductif. Analusis 1985, 13, 312-317.

19. Odin, G.S. Interlaboratory standards for dating purposes. In Numerical Dating in Stratigraphy; Odin, G.S., Ed.; John Wiley \& Sons: Chichester, UK, 1982; pp. 123-148.

20. Lee, J.Y.; Marti, K.; Severinghaus, J.P.; Kawamura, K.; Yoo, H.S.; Lee, J.B.; Kim, J.S. A redetermination of the isotopic abundances of Atmospheric Ar. Geochim. Cosmochim. Acta 2006, 70, 4507-4512. [CrossRef]

21. Steiger, R.; Jäger, E. Subcommission on Geochronology: Convention on the use of decay constants in geo- and cosmochronology. Earth Plan. Sci. Lett. 1977, 36, 359-362. [CrossRef]

22. Bonhomme, M.; Thuizat, R.; Pinault, Y.; Clauer, N.; Wendling, R.; Winkler, R. Méthode de Datation Potassium-Argon. Appareillage et Technique; Rapport technique du Centre de Géochimie de la Surface; Univ. Louis Pasteur: Strasbourg, France, 1975; 53p.

23. Li, M.; Fang, X.; Galy, A.; Wang, H.; Song, X.; Wang, X. Hydrated sulfate minerals (bloedite and polyhalite): Formation and paleoenvironmental implications. Carbonates Evaporites 2020, 35, 126. [CrossRef]

24. Harper, C.T. Graphic solution to the problem of 40Ar loss from metamorphic minerals. Eclog. Geol. Helv. 1970, 63, 119-140.

25. Clauer, N. The rubidium-strontium method applied to sediments: Certitudes and uncertainties. In Numerical Dating in Stratigraphy; Odin, G.S., Ed.; John Wiley and Sons, Ltd.: Hoboken, NJ, USA, 1982; pp. 245-276.

26. McArthur, J.M.; Howarth, R.J.; Bailey, T.R. Strontium isotope stratigraphy: LOWESS Version 3: Best fit to the marine Sr-isotope curve 0-509 Ma and accompanying look-up table for deriving numerical age. J. Geol. 2001, 109, 155-170. [CrossRef] 